\title{
PENINGKATAN PERILAKU HEMAT ENERGI BAGI SISWA SMA DAN PENERAPAN SNI PADA RUANG BELAJAR
}

\author{
1,3,4 Program Studi Teknik Elektro, Universitas Tarumanagara \\ Email:endahs@ft.untar.ac.id \\ Email:yohanesc@ft.untar.ac.id \\ Email:jonif@ft.untar.ac.id \\ 2 Jurusan Psikologi, Universitas Tarumanagara \\ Email: fransiscar@fpsi.untar.ac.id
}

Endah Setyaningsih ${ }^{1}$, Fransisca Iriani Roesmaladewi², Yohanes Calvinus ${ }^{3}$, dan Joni Fat ${ }^{4}$

\begin{abstract}
There was a blackout in early August 2019, forcing everyone to think about electricity. Some expressed the need for management reform, use of new renewable energy, and promoting energy-saving behavior. However, energy saving behavior without good knowledge will make it difficult to carry out the behavior. For this reason, the community service team collected data through a questionnaire to determine the energy saving knowledge of lighting for students. Furthermore, there is provision on energy saving lighting and practice in the field to determine the extent to which energy saving is implemented in the study room. This practice is in the form of measuring the light intensity of the study room, to find out its value so that if it is not enough, it is necessary to take action to comply with SNI standards. The presentation of the lighting field briefing contained, among other things, the explanation that saving energy does not mean reducing the use of electric power alone, but rather that saving energy must maintain the quality of lighting. Based on the results of the pre test, students have a high desire to behave energy-saving by $91.3 \%$ and have confidence in the results of a behavior and an evaluation of the results of a high behavior is $99.5 \%$. The study room illumination shows a value that is not in accordance with the SNI, which is between 125 Lux to 150 Lux. This value is far from the SNI standard, which is 350 Lux for classrooms. Based on the results of the application of this SNI, then the lighting design is carried out through simulation using the Dialux software and the installation of energy-saving lamps in the study room, so that it reaches the SNI standard.
\end{abstract}

Key words: Knowledge of energy saving, lighting, pre test, SNI, and Illuminance.

\begin{abstract}
ABSTRAK
Terjadinya pemadaman listrik pada awal Agustus 2019, memaksa semua orang untuk berpikir tentang kelistrikan. Sebagian menyatakan perlunya pembenahan manajemen, perlunya pengelolaan/penggantian sistem, dan usulan penggunaan energi baru terbarukan. Selain itu masih terdapat hal lain, yaitu peningkatan perilaku hemat energi (HE), antara lain berupa peningkatan pengetahuan HE. Namun HE kadang-kadang diartikan lain, yaitu hanya sekedar mematikan lampu, tanpa memperhatikan kualitas visual. Untuk itu tim pengabdian kepada masyarakat ini melakukan pengambilan data melalui kuisioner untuk mengetahui pengetahuan HE kepada siswa SMA N 23 Jakarta. Selanjutnya dilakukan pembekalan mengenai HE dan praktik di lapangan untuk mengetahui sejauh mana pelaksanaan HE yang ada sekolah tersebut. Praktik ini antara lain berupa pengukuran intensitas cahaya ruang belajar, untuk mengetahui nilainya sehingga jika kurang perlu dilakukan tindakan untuk disesuaikan dengan standar SNI. Penyampaian pembekalan bidang pencahayaan, antara lain berisi tentang penjelasan bahwa HE bukan berarti mengurangi penggunaan daya listrik saja, tapi lebih diutamakan bahwa HE harus tetap menjaga kualitas pencahayaan. Berdasarkan hasil pre test, siswa memiliki keinginan tinggi untuk berperilaku hemat energi sebesar 91,3\% dan memiliki keyakinan akan hasil dari suatu perilaku dan evaluasi terhadap hasil perilaku yang tinggi sebesar 99,5\% Tingkat pencahayaan/Iluminansi ruang belajar menunjukkan nilai yang kurang sesuai dengan SNI, yaitu antara 125 Lux sampai dengan 150 Lux. Nilai ini jauh dari standar SNI, yaitu 350 Lux untuk ruang kelas. Berdasarkan hasil penerapan SNI ini, selanjutnya dilakukan perancangan pencahayaan melalui simulasi dengan menggunakan perangkat lunak Dialux dan pemasangan lampu HE pada ruang belajar tersebut, sedemikian sampai mencapai standar SNI.
\end{abstract}

Kata kunci: Pengetahuan hemat energi, pencahayaan, pre test, SNI, dan Iluminansi. 


\section{PENDAHULUAN}

SMA N 23 Tomang, merupakan salah satu sekolah menengah atas yang ada di kelurahan Tomang. Wilayah kelurahan Tomang, berada tidak jauh dari Universitas Tarumanagara (sekitar $3 \mathrm{~km}$ ). Hal ini merupakan salah satu pertimbangan untuk melakukan kegiatan pengabdian kepada masyarakat, karena kemudahan jangkauan, kemanfaatan, dan kesesuain dengan bidang unggulan serta arahan Universitas Tarumanagara. Salah satu program kelurahan Tomang adalah upaya untuk meningkatkan kualitas lingkungan fisik dan sosial, yang dapat memberikan keamanan, kenyamanan, ketentraman, dan kesehatan. Upaya ini bila diuraikan lebih lanjut adalah berhubungan dengan penghematan energi. Meskipun tidak tergambar dengan gamblang sebagai sadar hemat energi. Untuk itu kegiatan PKM ini ingin mendorong banyak orang untuk sadar energi, yang saat ini merupakan salah satu program utama pemerintah, yang dituangkan dalam banyak instruksi dan peraturan sebagai dasar hukum [1][2][3][4][5][6].

SMA Negeri 23 ini merupakan satu-satunya SMA Negeri yang ada di Kelurahan Tomang. Sekolah ini telah terakreditasi 'A", terdiri dari 19 kelas, 4 laboratorium dan satu perpustakaan. Jurusan atau kompetensi keahlian di sekolah ini terdiri dari Matematika dan Ilmu Alam (MIA) dan Ilmu-ilmu Sosial (IIS), yang terbagi untuk siswa kelas X sampai dengan kelas XII. Gambar 1, menunjukkan salah satu pencahayaan ruang kelas yang menggunakan lampu TL-8, lampu yang saat ini disebut sebagai lampu yang kurang hemat energi, dibandingkan dengan lampu TL-LED [7][8].
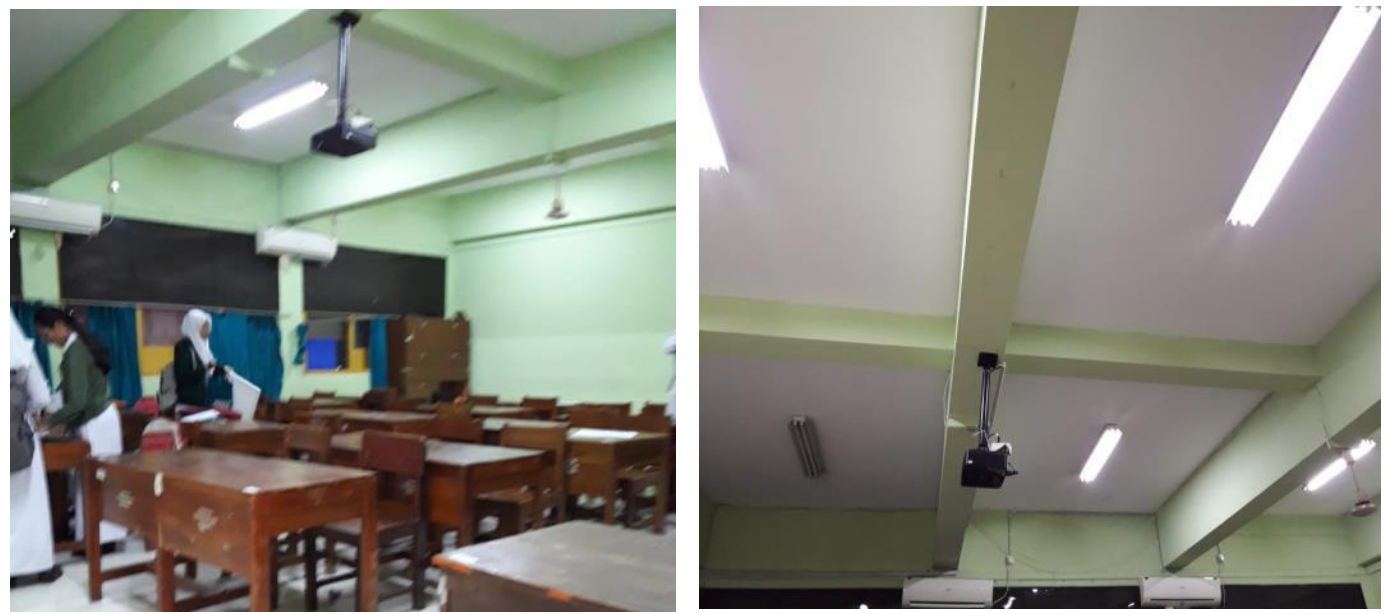

Gambar 1. Pencahayaan ruang kelas SMA N 23 (eksisting) dengan Lampu TL-8

Sesuai dengan hasil tinjauan lapangan ke beberapa ruang kelas dan berdiskusi dengan para guru dan beberapa siswa di SMA N 23 Tomang, terutama tentang penghematan energi, program pemerintah tentang hemat energi, dan perilaku siswa dalam menunjang hemat energi, maka diperoleh bahwa terdapat beberapa permasalahan yang ada dalam hubungannya dengan hemat energi. Permasalah tersebut antara lain kurangnya pengetahuan tentang hemat energi dan kesalah pahaman dalam mengartikan istilah hemat energi serta pengetahuan dalam penghitungan konsumsi energi. Selain itu juga banyak siswa dan guru yang kurang pengetahuan tentang jenis lampu yang hemat energi. Kondisi ruang kelas yang serasa gelap (meski pada siang hari), karena kurangnya tingkat pencahayaan dalam ruang. Melihat kondisi pencahayaan ruang kelas ini, maka dapat diperkirakan pencahayaan ruang kelas belum sesuai dengan standar nasional Indonesia (SNI).

Solusi untuk permasalahan yaitu dilakukan sosialisasi hemat energi dan bimbingan teknis (bimteks) kepada guru dan siswa di SMAN 23 Tomang. Sosialisasi hemat energi dan bimteks 
meliputi pemahaman tentang istilah hemat energi dan bagaimana berperilaku HE, pemahaman tentang penerapan hemat energi melalui inovasi teknologi, pemahaman lampu hemat energi untuk ruang kelas dan mengevaluasi pencahayaan ruang dan praktik penggunaan alat ukur cahaya (luxmeter), serta penyampaian pengetahuan tentang SNI, khususnya bidang pencahayaan. Permasalahan mitra dan solusinya dapat dilihat pada Tabel 1. Kontribusi atau partisipasi mitra (SMA N 23 Tomang) dan peran mitra secara in kind dalam kegiatan PKM ini, yaitu memberikan waktu kepada siswa dan guru untuk mengikuti bimteks HE, menyediakan ruang kelas dilakukan pengukuran intensitas cahayanya, memberikan kesempatan salah satu guru untuk menjadi pendamping siswa, dan menyediakan ruang/auditorium untuk kegiatan tim PKM di sekolah SMA N 23 Tomang.

Tabel 1. Permasalahan Mitra dan Solusi Permasalahan

\begin{tabular}{|c|c|c|c|}
\hline No & $\begin{array}{l}\text { Kelompok } \\
\text { Bidang Permasalahan }\end{array}$ & $\begin{array}{l}\text { Permasalahan } \\
\text { Mitra }\end{array}$ & Solusi Permasalahan \\
\hline 1 & $\begin{array}{l}\text { Pengetahuan HE dan } \\
\text { lampu HE }\end{array}$ & $\begin{array}{l}\text { Kurangnya } \\
\text { pengetahuan } \mathrm{HE}\end{array}$ & $\begin{array}{l}\text { 1.Bimteks tentang HE } \\
\text { 2. Melakukan Pre test tentang HE. }\end{array}$ \\
\hline 2 & $\begin{array}{l}\text { Standar } \\
\text { Pencahayaan }\end{array}$ & $\begin{array}{l}\text { Kurangnya tingkat } \\
\text { pencahayaan } \\
\text { ruang }\end{array}$ & $\begin{array}{l}\text { 1. Observasi pencahayaan ruang } \\
\text { 2. Ukur cahaya ruang } \\
\text { 3. Cek dengan standar SNI atau } \\
\text { standar pencahayaan lainnya }\end{array}$ \\
\hline 3 & Tingkat cahaya & $\begin{array}{l}\text { Kurangnya tingkat } \\
\text { pencahayaan dalam } \\
\text { ruang }\end{array}$ & $\begin{array}{l}\text { 1. Perancangan cahaya ruang } \\
\text { 2. Direncanakan mengganti atau } \\
\text { menambah dengan lampu LED }\end{array}$ \\
\hline 4 & $\begin{array}{l}\text { Pemahaman Penerapan } \\
\text { Inovasi Teknologi }\end{array}$ & $\begin{array}{l}\text { Kurangnya } \\
\text { pemahaman } \\
\text { inovasi teknologi }\end{array}$ & $\begin{array}{l}\text { Direncanakan otomatisasi on/off } \\
\text { ruang kelas }\end{array}$ \\
\hline
\end{tabular}

\section{METODE PELAKSANAAN}

Tempat pelaksanaan PKM untuk SMA N 23 adalah di ruang kelas Teknologi Informasi dan Komputer (TIK) dengan tahapan-tahapan pelaksanaan kegiatan PKM sebagai berikut:

Tahap 1, yaitu pengukuran pengetahuan hemat energi kepada siswa. Tahap 2, yaitu observasi dan pengukuran tingkat pencahayaan ruang kelas dengan menggunakan alat ukur Luxmeter. Berdasarkan hasil ukur pencahayaan ruang kelas jika hasilnya kurang baik, yaitu nilai tingkat pencahayaan/iluminasi (lux) jauh dari standar SNI, maka selanjutnya menyiapkan perancangan ruang dengan simulasi menggunakan software pencahayaan (Dialux). Dilanjutkan dengan rencana melakukan retrofit lampu ruang kelas dan rencana otomatisasi on-off ruang kelas.

Pembahasan dalam makalah ini mencakup pengambilan data berupa pre test, pengukuran pencahayaan ruang kelas dan simulasi Dialux untuk memperoleh jumlah lampu yang nantinya akan dipasang pada ruang tersebut. Hasil pemasangan lampu dan hasilnya dalam memenuhi SNI, serta otomatisasi on-off akan disampaikan dalam makalah selanjutnya. Gambar 2, menunjukkan serangkaian kegiatan Bimteks di SMA N 23 Tomang. 


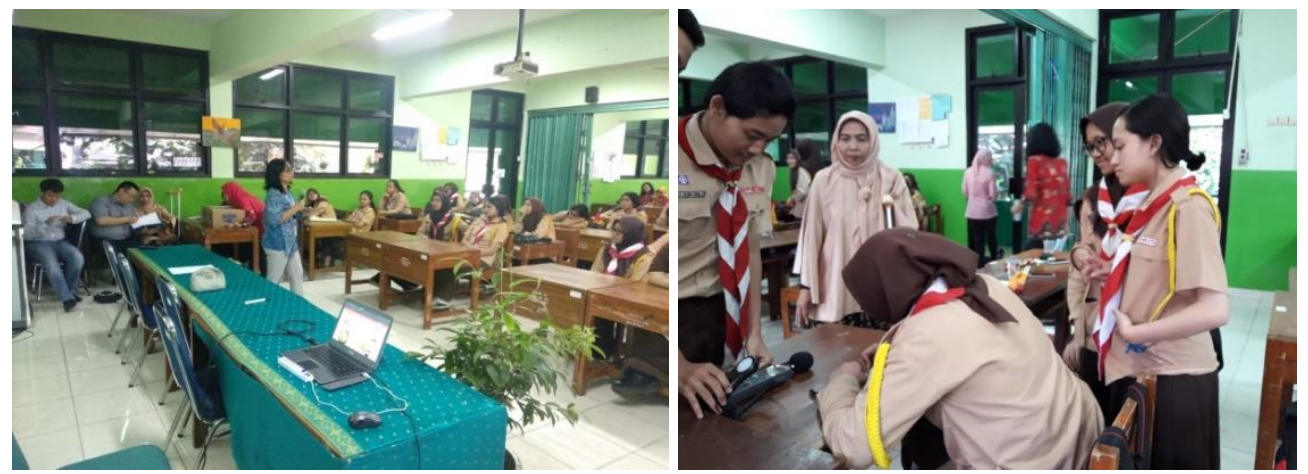

Gambar 2. Serangkaian kegiatan Bimteks di SMA N 23 Tomang

\section{HASIL DAN PEMBAHASAN}

Upaya memahami perilaku individu merupakan topik sentral dalam bidang psikologi. Teori dikembangkan oleh Ajzen (2005) theory of planned behavior yang ditujukan untuk memprediksi perilaku individu secara lebih spesifik. Perilaku individu untuk berhemat energi dipengaruhi oleh niat (intention) yaitu berkeinginan untuk berperilaku hemat energi. Niat untuk berperilaku dipengaruhi oleh 3 faktor: sikap (attitude), norma subjektif (subjective norm), dan persepsi kontrol perilaku/Perceived Behavioral Control (PBC)[9].

Pada saat pengambilan data pre test tentang pengetahuan dan sikap terhadap hemat energi, tim PKM Untar dibantu oleh sejumlah mahasiswa Psikologi. Pengambilan data kuisioner ini diikuti oleh siswa kelas XI IPA dan IPS yang berjumlah 184 siswa. Rentang usia subyek pada penelitian ini adalah 15 tahun sampai dengan 18 tahun. Subyek penelitian terdiri dari 77 siswa laki-laki $(41,85 \%)$ dan 107 siswa perempuan $(58,15 \%)$. Subyek dalam penelitian ini yang memiliki keinginan tinggi untuk berperilaku hemat energi sebesar 91,3\% (168 siswa), subyek yang memiliki keinginan sedang untuk berperilaku hemat energi sebesar 2,7\% (5 siswa), subyek yang memiliki keinginan rendah untuk berperilaku hemat energi sebesar 6\% (11 siswa). Hal tersebut dapat disimpulkan bahwa sebagian besar subyek memiliki keinginan yang tinggi untuk berperilaku hemat energi. Gambar 3, menunjukkan gambaran niat (keinginan) berperilaku hemat energi dan gambaran sikap terhadap perilaku siswa. Subyek yang memiliki keyakinan akan hasil dari suatu perilaku dan evaluasi terhadap hasil perilaku yang tinggi sebesar 99,5\% (183 siswa), sedangan subyek yang memiliki keyakinan akan hasil dari suatu perilaku dan evaluasi terhadap hasil perilaku yang rendah sebesar $0,5 \%$ (1 (satu) siswa). Hal tersebut dapat disimpulkan bahwa siswa memiliki keyakinan akan hasil dari suatu perilaku dan evaluasi terhadap hasil perilaku yang tinggi.

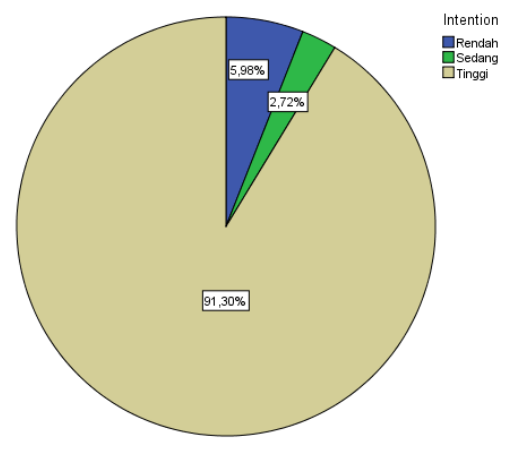

(a)

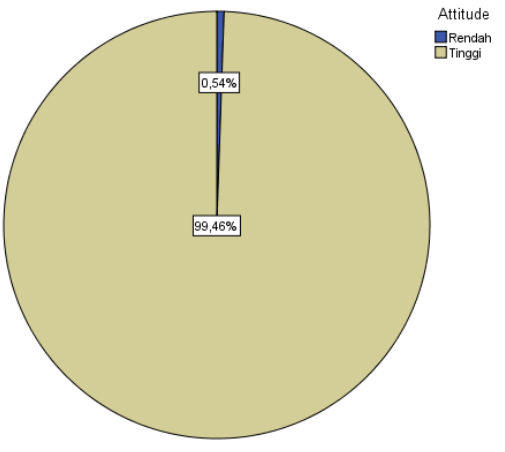

(b)

Gambar 3. Gambaran (a) niat (keinginan) berperilaku) dan (b) sikap hemat energi pada siswa 
Subyek yang memiliki norma subyektif tinggi yaitu dengan persentase 54,3\% (100 siswa), subyek yang memiliki norma subyektif yang sedang memiliki persentase 11,4\% (21 siswa), dan subyek yang memiliki norma subyektif yang rendah memiliki persentase 34,2\% (63 siswa). Nilai norma subyektif siswa hanya mencapai $54,3 \%$, yaitu sekitar setengah dari 185 siswa yang menjadi subyek penelitian ini, dapat disimpulkan bahwa keyakinan individu siswa terhadap harapan normatif orang lain yang menjadi rujukannya, seperti keluarga, teman, dan guru serta motivasi untuk mencapai harapan tersebut masih belum tercapai. Gambar 4, menunjukkan gambaran norma subyektif dan persepsi kontrol perilaku siswa. Untuk itu para guru dilingkup sekolah SMA N 23 perlu memberikan contoh-contoh praktik hemat energi. Selain itu adanya teknologi juga dapat membantu praktik hemat energi. Pada kegiatan PKM ini diberikan contoh 2 ruangan yang digunakan sebagai model ruang hemat energi, yaitu adanya lampu hemat energi dan otomatisasi on-off lampu di ruangan.

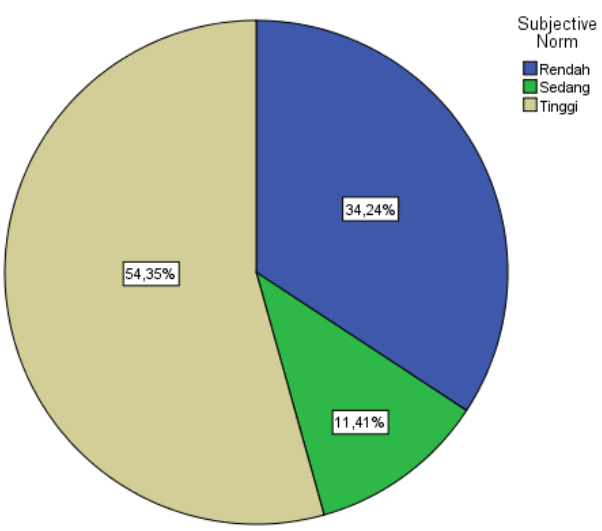

(a)

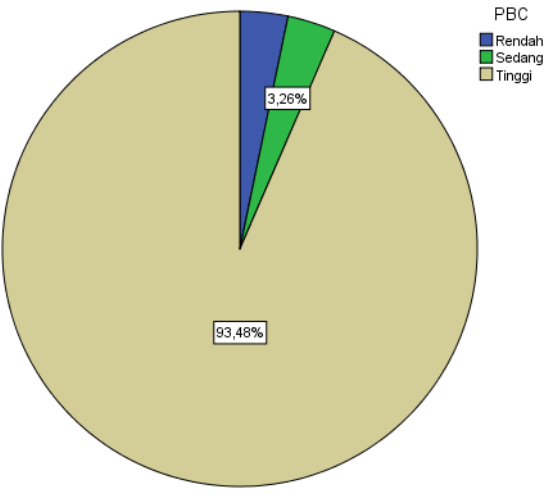

(b)

Gambar 4. Gambaran (a) norma subyektif dan (b) persepsi kontrol perilaku siswa.

Persepsi kontrol perilaku (mudah atau sulitnya mewujudkan suatu perilaku tertentu). Hal ini ditentukan oleh keyakinan individu mengenai ketersediaan sumber daya berupa peralatan dan kesempatan yang mendukung/menghambat perilaku dalam mewujudkan perilaku tersebut. Subyek yang memiliki persepsi kontrol perilaku yang tinggi memiliki persentase 93,5\% (172 siswa), subyek yang memiliki persepsi kontrol perilaku yang sedang memiliki persentase 3,3\% (6 siswa), dan subyek yang memiliki persepsi kontrol perilaku yang rendah memiliki persentase 3,3\% (6 siswa). Hal tersebut dapat disimpulkan bahwa siswa memiliki persepsi kontrol perilaku yang tinggi. Untuk menjaga agar PBC siswa tetap tingi, maka adanya model ruang hemat energi, yaitu adanya lampu hemat energi dan otomatisasi on-off lampu di ruangan sebagai salah satu hasil PKM ini adalah sangat baik.

Bimbingan teknis yang disampaikan pada siswa dan guru, diawali dengan pembekalan materi tentang cara-cara penghematan energi AC dan lampu, ventilasi alam dan jenis-jenis lampu hemat energi. Setelah itu dilakukan praktik pengukuran tingkat intensitas cahaya dalam ruang kelas menggunakan luxmeter dan praktik pengukuran suhu dalam ruang kelas dengan termometr infrared. Selain itu siswa juga dikenalkan alat ukur panjang, yang biasanya menggunakan meteran, saat itu dikenalkan alat distance meter digital, yang bekerja menggunakan infra merah. Berdasarkan berbagai pertanyaan yang diajukan para siswa dan guru terlihat bahwa mereka sangat tertarik dengan kegiatan ini. Hal ini mengindikasikan bahwa siswa dan guru paham terhadap materi yang disampaikan, sehingga dapat dikatakan tujuan pelaksanaan kegiatan PKM ini berhasil. Diharapkan bahwa siswa dan guru akan selalu berperilaku hemat energi dalam kesehariannya, baik di sekolah maupun rumah. 
Saat pelaksanaan pengukuran pencahayaan ruang kelas, tim PKM dibantu oleh 3 orang mahasiswa Teknik Elektro Untar. Pengukuran pencahayaan meliputi pengukuran iluminnasi/tingkat pencahayaan ruang kelas TIK (panjang $9 \mathrm{~m}$, lebar $8 \mathrm{~m}$, dan tinggi 3,2 m). Selain melakukan pengukuran, juga dibuatkan dokumentasi berupa foto dan video kegiatan. Total titik pengukuran sebanyak 56 titik ukur/TU. Ruangan yang dijadikan tempat pengukuran memiliki meja kerja dengan tinggi 0,73 meter, dan menggunakan Lampu TLD-8 32 Watt, sebanyak 12 lampu. Pengukuran dilakukan dengan cara mengukur lampu dengan menggunakan lux meter yang diletakkan diatas tripod yang tingginya diatur sesuai tinggi bidang kerja yaitu $0,73 \mathrm{~m}$ dari lantai dan diletakkan tegak lurus terhadap bidang. Suasana dan denah ruang TIK, ditunjukkan pada Gambar 5, tampak pada gambar tersebut terdapat layar monitor televisi 50 inci pada bagian depan dan terdapat 40 set komputer yang berfungsi untuk pembelajaran materi TIK. Berdasarkan hasil pengukuran ruang kelas TIK didapatkan hasil tingkat pencahayaan/iluminnasi E rata rata sebesar 116,18 Lux, nilai E min sebesar 70,02 Lux, dan didapatkan nilai E maks sebesar 166,6 Lux. Nilai E rata-rata jauh lebih kecil dari nilai E rata-rata SNI yaitu 350 Lux (SNI, 2011)[10]. Tabel 2, merupakan hasil ukur iluminansi ruang keas TIK.

Tabel 2, merupakan hasil ukur iluminansi ruang keas TIK.

\begin{tabular}{|c|c|c|c|c|c|c|c|c|}
\hline \multirow{2}{*}{$\begin{array}{l}\text { Pintu } \\
\text { masuk }\end{array}$} & \multicolumn{7}{|c|}{ TELEVISI } & \multirow[b]{2}{*}{$\mathbf{J}$} \\
\hline & 80,5 & 104,7 & 84,5 & 70,5 & 91,1 & 92,6 & 63,9 & \\
\hline \multirow{2}{*}{$\begin{array}{l}\mathbf{J} \\
\mathbf{E}\end{array}$} & 103,1 & 118,2 & 101,4 & 91,7 & 96,1 & 99,5 & 70,02 & \multirow{2}{*}{$\begin{array}{l}\mathbf{E} \\
\mathbf{N}\end{array}$} \\
\hline & 119,1 & 136,4 & 117,3 & 103,4 & 105,7 & 97,4 & 73,3 & \\
\hline \multirow{2}{*}{$\begin{array}{l}\text { N } \\
\text { D }\end{array}$} & 146,5 & 165,9 & 148,3 & 118,2 & 121,9 & 107,7 & 79,2 & \multirow{2}{*}{$\begin{array}{l}\text { D } \\
\text { E }\end{array}$} \\
\hline & 147,1 & 166,1 & 143,5 & 121,1 & 118,1 & 116,5 & 86,1 & \\
\hline $\mathbf{E}$ & 147,6 & 160,8 & 143,5 & 125,6 & 132,3 & 129,1 & 99,8 & $\mathbf{L}$ \\
\hline \multirow{2}{*}{$\begin{array}{l}\mathbf{L} \\
\mathbf{A}\end{array}$} & 147,1 & 166,6 & 143,5 & 128,7 & 144,9 & 148,1 & 104,5 & \multirow[t]{2}{*}{$\mathbf{A}$} \\
\hline & 113,9 & 142,1 & 124,6 & 115,5 & 126,7 & 146,8 & 101,6 & \\
\hline
\end{tabular}
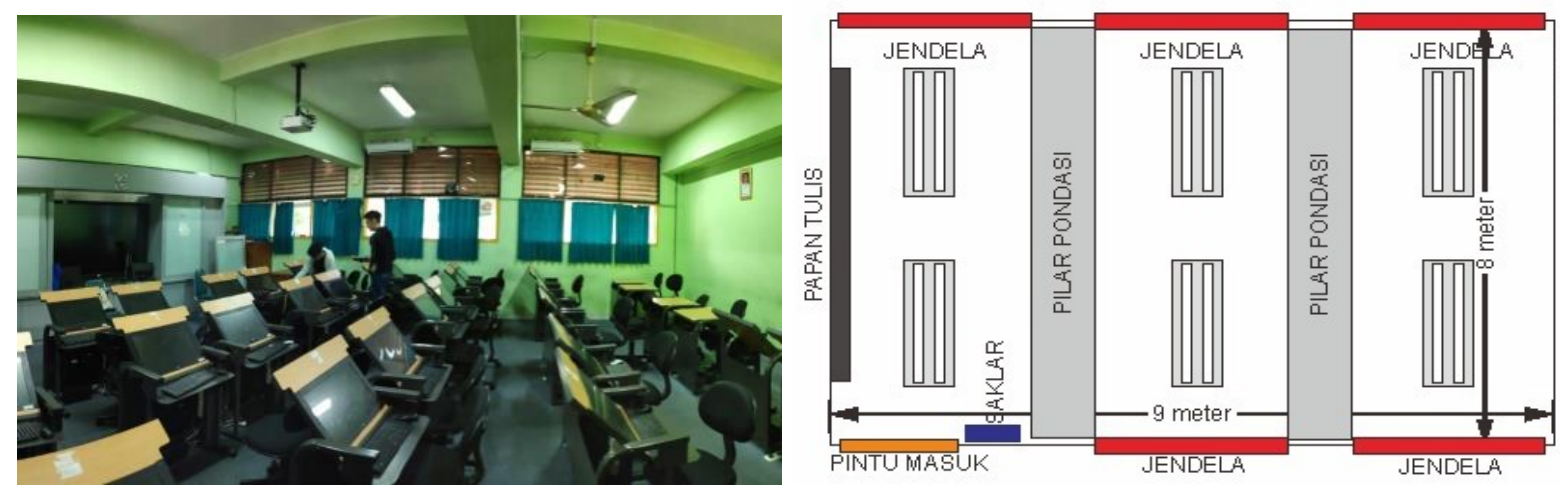

Gambar 5. Suasana dan denah ruang kelas TIK dengan ( $\mathrm{p}$ x 1 x t $=9$ × 8 × 3,2 m).

Selain dilakukan pengukuran, dilakukan juga perancangan pencahayaan ruang berupa simulasi dengan menggunakan Software Dialux, salah satu tujuannya adalah dapat memperkirakan jumlah lampu dan tipe lampu yang tepat yang akan dipasang diruang tersebut. Lampu dipasang dengan menempel pada plafon seperti kondisi existing. Melalui cara ini, menghasilkan tingkat cahaya yang kurang sesuai SNI, karena banyak cahaya yang terhalang oleh kolom. Namun jika lampu dipasang sejajar kolom, akan membuat biaya pemasangan yang tinggi, juga membuat jarak lampu ke meja terlalu dekat, untuk itu direncanakan nantinya menambah beberapa lampu di kolom. 
Perancangan/desain pencahayaan ruang kelas TIK, dilakukan beberapa kali, dari desain 1 hingga ke desain 3. Hal ini dilakukan, karena sulitnya memperoleh luminer/rumah lampu/kap untuk 3 lampu atau 4 lampu dalam 1 (satu) kap yang harganya ekonomis, dan disesuaikan dengan suasana di ruang tersebut. Selain itu juga sulit ditemukan lampu LED tube 18 watt 2100 lumen yang dijual dipasaran. Jenis lampu tersebut bisa diperoleh dengan cara memesan khusus ke pabrikan lampu, namun harus dalam jumlah yang banyak. Digunakan kap lampu tipe $\mathrm{V}$, dengan 1 kap lampu untuk 2 lampu LED tube. Sesuai kode 865 pada lampu ini, temperatur warnanya adalah $6500 \mathrm{~K}$, yaitu kategori daylight dan Color Rendering Index/CRI atau renderasi 80\%. Panjang lampu 1,2 m, sama dengan lampu yang terpasang (existing).

Nilai E rata-rata dari desain 3, opsi 1, masih di atas 350 Lux, maka dilakukan optimisasi dengan mendesain lagi (opsi 2), dan diperoleh hasil simulasi pencahayaan ruang kelas TIK (desain 3, opsi 2) seperti Gambar 6 dan Gambar 7, merupakan False color rendering ruang kelas TIK (desain 3, opsi 2). Desain opsi 2 ini menghasilkan E rata 358 Lux, nilai ini sesuai standar SNI yaitu 350 Lux. Tampak dari Gambar 3, isoline di bidang kerja menunjukkan nilai iluminansi berada pada nilai yang tidak jauh dari 350 lux untuk zona utama (tempat siswa belajar), sedangkan nilai E sebesar 280 Lux berada dipinggir-pinggir ruang. Nilai kemerataan membaik, yaitu 0,775. Jumlah lampu menjadi lebih sedikit, yaitu 8 untuk tiap kolom, total ada 24 lampu (total daya $24 \times 14,5$ watt $=$ 348 watt . Pemasangan menggunakan luminer atau kap lampu untuk 1 kap berisi 2 lampu, jadi membutuhkan $12 \mathrm{kap}$ lampu. Desain ini menghasilkan penggunaan daya yang lebih baik yaitu sebesar 4,83 W/m² atau 1,35 W/m²/100 lux (luas area $72 \mathrm{~m} 2$ ). Desain 3 opsi 2 ini yang akan digunakan untuk retrofit ruang kelas TIK SMA N 23 Tomang.

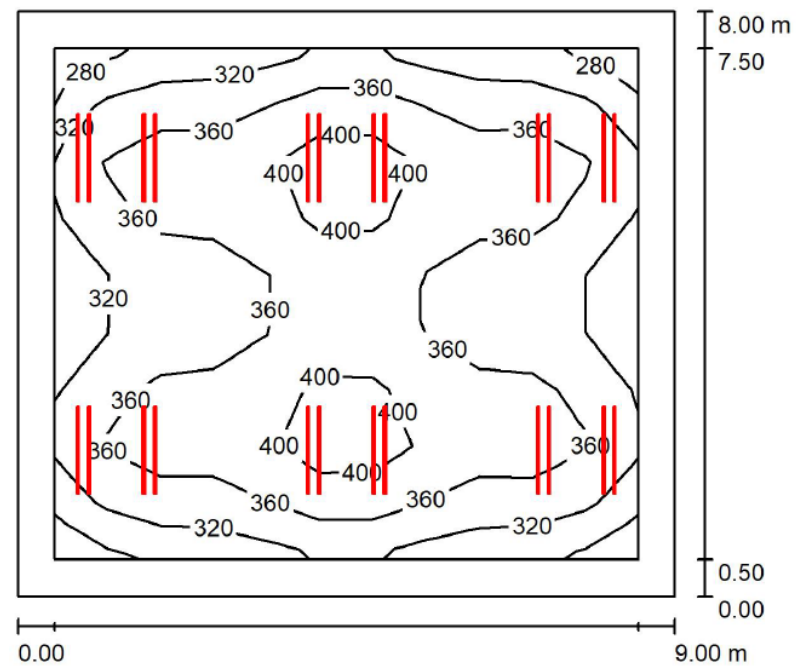

Height of Room: 3.200 m, Mounting Height: 3.200 m, Light loss factor: 0.90

Gambar 6. Hasil simulasi pencahayaan ruang Kelas TIK (desain 3, opsi 2, Final) 


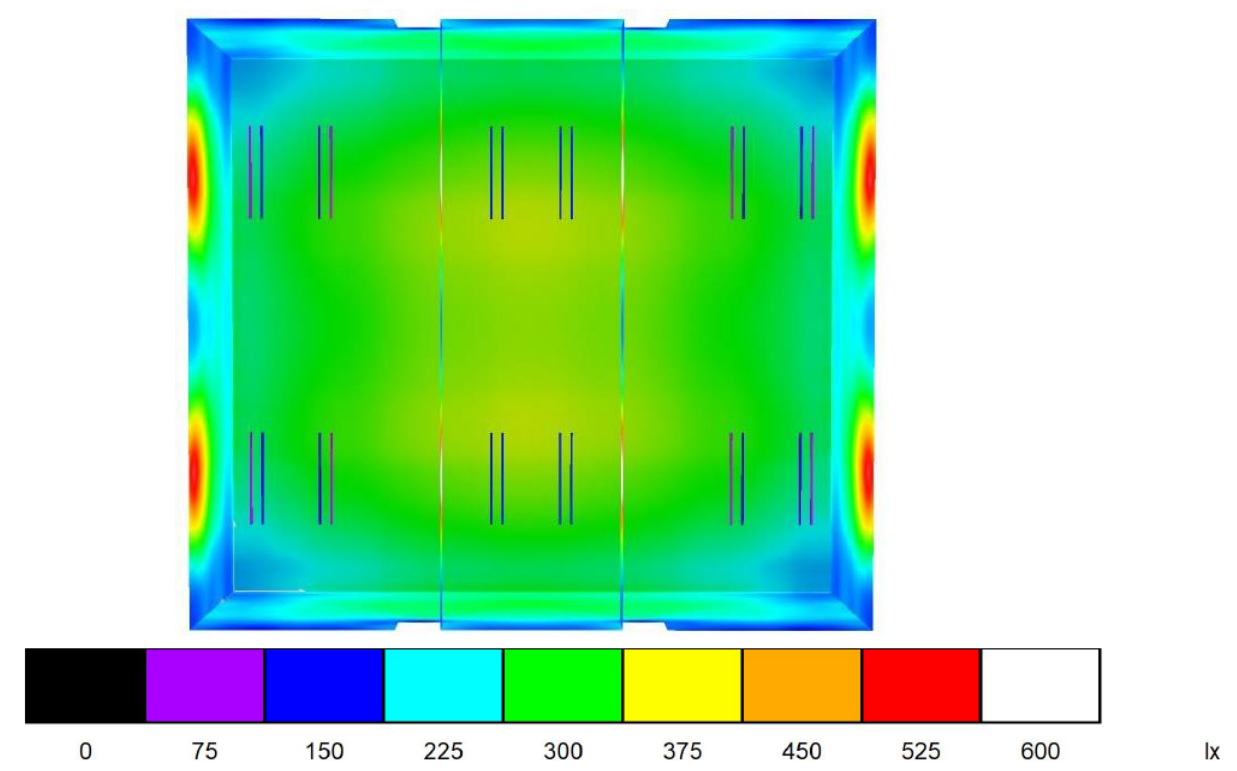

Gambar 7. False color rendering ruang kelas TIK (desain 3, opsi 2, Final)

Jumlah lampu ruang TIK existing (terpasang) adalah 12 lampu, dengan daya 36 watt, menggunakan lampu TLD-8 (jenis fluorescent), sehingga membutuhkan $12 \times 36$ watt $=432$ watt, untuk luas $72 \mathrm{~m} 2$. Jadi penggunaan daya/m2 adalah $432 / 72=6 \mathrm{watt} / \mathrm{m} 2$ dan menghasilkan iluminansi sebesar 166,6 lux. Sementara standar SNI 350 lux, atau setara dengan 2,1 x 166,6 lux. Jadi untuk mencapai 350 lux, maka perlu daya/m2 sebesar 2,1 x $6=12,65 \mathrm{watt} / \mathrm{m} 2$. Lampu LED tube membutuhkan $4,83 \mathrm{watt} / \mathrm{m} 2$, dalam menghasilkan iluminansi sebesar 350 lux. Jadi terdapat penghematan energi yang signifikan, yaitu sebesar $7,82 \mathrm{watt} / \mathrm{m} 2$, untuk 1 (satu) ruangan. Atau dalam hitungan daya adalah membutuhkan daya 2,1 x 432 watt $=907,2$ watt (untuk lampu TLD8, daya 36 watt) dan 348 watt (untuk lampu LED tube 14,5 watt), sehingga ada penghematan sebesar $(907,2-348)=559,2$ watt untuk satu ruangan. Catatan perhitungan ini belum memperhitungkan rugi-rugi daya lampu TLD-8, yaitu sekitar 6-9 watt.

\section{KESIMPULAN DAN SARAN}

- Siswa SMA N 23 Tomang memiliki keinginan tinggi untuk berperilaku hemat energi, yaitu sebesar 91,3\% (168 siswa, terhadap 185 siswa sebagai subyek penelitian ini).

- Tingkat pencahayaan/iluminansi (E) rata rata ruang kelas TIK sebesar 116,177 Lux dan ruang laboratorium IPA sebesar 152,034 Lux. Pengukuran pada saat kondisi existing (sebelum dilakukan retrofit lampu). Nilai E rata-rata jauh lebih kecil dari nilai E rata-rata SNI yaitu 350 Lux dan 500 Lux.

- Ruang kelas TIK perlu dilakukan penambahan lampu untuk mencapai standar SNI.

- Melalui simulasi, penggunaan lampu TLD-8 pada ruang kelas TIK membutuhkan 12,65 watt $/ \mathrm{m} 2$ dan dengan TL-LED tube membutuhkan 4,83 watt $/ \mathrm{m} 2$, dalam menghasilkan iluminansi sebesar 350 lux. Terdapat penghematan energi yang signifikan, yaitu sebesar $7,83 \mathrm{watt} / \mathrm{m} 2$ atau sebesar 559,2 watt untuk satu ruangan kelas.

Ucapan Terima Kasih (Acknowledgement).

PKM ini merupakan bagian dari PKM hibah Ristekdikti dalam skema desentralisasi, terimakasih atas pendanaannya. Terimakasih juga kepada LPPM Universitas Tarumanagara yang memberikan dana pendamping, kepada Kepala Sekolah SMA N 23 Tomang, yang bertindak sebagai mitra, dan terimakasih kepada PT Honoris Industry melalui CSR nya yang telah menyumbangkan 50 lampu TL-LED tube. 


\section{REFERENSI}

Instruksi Presiden Nomor 13 tahun 2011 tentang penghematan energi dan air

Peraturan Menteri ESDM nomor 13 tahun 2012 tentang Penghematan Pemakaian Tenaga Listrik.

Peraturan Menteri ESDM nomor 14 tahun 2012 tentang Manajemen Energi

Peraturan Pemerintah nomer 70 tahun 2009 tentang Konservasi Energi.

Panduan Penghematan Energi di Gedung Pemerintah, Usaid Indonesia dan ESDM, 2014

Instruksi Presiden Nomor 13 tahun 2011.

Candra, H; Setyaningsih, E; dan Tji Beng, J. (2018). Analisis Efisiensi Konsumsi Daya Listrik dan Biaya Operasional Lampu TL-LED terhadap Lampu TL-T8. Jurnal Muara Sains, Teknologi, Kedokteran, dan Ilmu Kesehatan Vol. 2, No. 1, April 2018, hal. 186-193, ISSN- L 25796410

International Energy Agency, “Energy Efficiency 2017,” International Energy Agency, Jakarta, 2017.

Roesmaladewi, F.I., Setyaningsih, E., Widodo, L. (2016). Peran Sikap, Norma Subyektif dan Perceived Behavior Control Terhadap Intensi Berperilaku Hemat Energi Pada Siswa SMP, Conference on Management and Behavioral Studies, Universitas Tarumanagara, Jakarta, 27 Oktober 2016, halaman 774, ISSN No: 2541-3400, e-ISSN No. 2541-2850.

SNI No. 6197-2011, (2011) Konservasi Energi pada Sistem Pencahayaan, 2011, Badan Standardisasi Nasional. 